\title{
MODEL KURVA DAN PENDUGAAN LAMA WAKTU PENGERINGAN TANDAN KOSONG, PELEPAH DAN SERAT TANDAN KOSONG KELAPA SAWIT
}

\author{
Y.Yuwana* \\ Jurusan Teknologi Pertanian, Fakultas Pertanian, Universitas Bengkulu \\ Penulis korespondensi: yuwana@unib.ac.id
}

\begin{abstract}
Biomassa originated from palm oil plant is potential to be processed into various industrial products. In the production line this material needs to dry into certain level of moisture content, mostly about 10\% (wet basis) and commonly called as dry material. It is advantageous if the dryng time to produce a dry material can be predicted. Prediction is usually approached by setting up drying model of the material. The most common drying model in formulated in the form of moisture ratio in function of drying time in which the moisture content is calculated in dry basis. On the other, in practice, the moisture content of material is expressed in wet basis. The objectives of this research were to determine the drying curves and to predict the drying times of palm oil empty fruit bunches, stem and fiber dried from solar dying and oven drying. Three series of experiments were carried out according to the types of materials. The results of the experiments revealed as follows. The curves produced by the solar energy dryer operating at drying temperatures ranged from $42^{\circ} \mathrm{C}$ to $54,5^{\circ} \mathrm{C}$ for both empty fruit bunches and stem were quadratic whereas the curves produced by the oven having temperature of $105^{\circ} \mathrm{C}$ for stem and fiber were linear and quadratic respectively. The form of curves obtained from the relationships between materials moisture contents determined in wet basis and drying times were similar to the curves of materials moisture ratios in function of drying times. The drying times of the solar energy drying for the empty fruit bunches were 20 hours dan 19.3 hours for Dura variety and Tenera variety respectively while those of stems were 16.3 hours and 17.9 hours respectively for Dura variety and Tenera variety. The drying times of the oven drying for the stems were 7.1 hours, 6.9 hours and 5.0 hours respectively for the lower, middle and upper parts of the stems. The drying times of oven drying for the fibers were 6.4 hours and 6.2 hours respectively for the outer and inner field stacks empty fruit bunches origins.
\end{abstract}

Keywords: drying curve, dryng time, fruit empty bunches, stem, fiber

\section{PENDAHULUAN}

Kelapa sawit merupakan salah satu komoditas perkebunan utama Indonesia. Pada tahun 2017 diperkirakan luas tanaman menghasilkan mencapai 7.799.000 ha dengan produksi CPO (Crude Palm Oil) sebesar 32.657.000 ton sehingga menempatkan Indonesia sebagai produsen CPO terbesar di Dunia (Dirjend. Perkebunan, 2015). Disamping menghasilkan CPO sebagai produk utama, budidaya tanaman sawit dan Pabrik Pengolahan Kelapa Sawit (PMKS) juga mengahsilkan material samping, diantaranya berupa: pelepah, tandan kosong, cangkang sawit dan serabut buah sawit. Dari perkebunan sawit, setiap hektar menghasilkan pelepah sekitar 10,4 ton berat kering (Fauzi, et al., 2012). Di PMKS Tandan Buah Segar (TBS) 
mengandung minyak sebanyak 20-25\%, inti (kernel) sebanyak 4-6\%, cangkang 5$9 \%$, tandan kosong (empty fruit bunch) $20-22 \%$, serat (fiber) $12-14 \%$ sedangkan buah brondolan menghasilkan minyak sebanyak 30-34\%, nut (biji) $15-17 \%$, serat (fiber) $14-30 \%$, sampah 2-10\%. Pelepah mulai banyak dimanfaatkan untuk pakan ternak tetapi juga prospektif untuk dijadikan pelet kayu. Tandan kosong dapat diproses menjadi serat putih yang dapat dipakai sebagai pengisi jok mobil, jok kursi dan sofa. Material ini juga dapat dipergunakan sebagai pembuat papan partikel dan produk kerajinan. Cangkang sawit sering digunakan langsung sebagai pengeras jalan tetapi banyak dipakai sebagai penghasil arang aktif. Seraput sawit sering digunakan langsung di PMKS sebagai bahan bakar bioler tetapi material ini juga dapat dijadikan serat yang penggunaannya sama dengan serat putih dan sangat potensial sebagai bahan isolator panas.

Tabel 1. Nilai kalori bagian tanaman kelapa sawit

\begin{tabular}{|c|c|c|}
\hline Komponen & $\begin{array}{c}\text { Nilai Kalor } \\
\text { rata-rata } \\
(\mathrm{kJ} / \mathrm{Kg})\end{array}$ & $\begin{array}{l}\text { Kisaran } \\
(\mathrm{kJ} / \mathrm{kg})\end{array}$ \\
\hline Tandan & 18.795 & 18.000- \\
\hline Kosong & & 19.920 \\
\hline Serat & 19.055 & $\begin{array}{c}18.800- \\
19580\end{array}$ \\
\hline Cangkang & 20.093 & $\begin{array}{l}19.500- \\
20.750\end{array}$ \\
\hline Batang & 17.471 & $\begin{array}{l}17.000- \\
17.800\end{array}$ \\
\hline Pelepah & 15.719 & $\begin{array}{l}15.400- \\
15.680\end{array}$ \\
\hline
\end{tabular}

(Sumber : Goenadi et al., 2008)

Produk akhir dari material samping tersebut perlu dikeringkan sampai kadar air tertentu, seperti pelet kayu 10-20\% dan kayu bakar $15-30 \%$ (Frike, 2009), serat pengisi jok 6\% (SNI 12-6094-1999), briket arang kayu maksimum 8\% (SNI 01-
6235 - 2000). Karena dikategorikan sebagai limbah dan banyak memerlukan tempat (bulky), pengeringan awal material berasal dari tanaman sawit ini biasanya dilakukan dengan penjemuran. Upaya perbaikan cara pengeingan sudah mulai dicobakan, misalnya Sulaiman et al. (2013) mengembangkan pengering energi surya terdiri dari sebuah ruang pengering yang disekat menjadi tiga dengan kapasitas total 8-10 $\mathrm{kg}$ tandan kosong kelapa sawit, yang dilengkapi dengan enam buah kolektor bertipe "double pass" dan kipas isap untuk mensirkulasikan udara pengering. Pengering dioperasikan dari pukul 09.30 pagi sampai pukul 05.00 sore. Pengering mampu menurunkan kadar air tandan kosong dari kadar air 63$79 \%$ menjadi $3,71-4,18 \%$ dalam waktu 13,5-21 jam. Di Jurusan Teknologi Pertanian, telah dikembangkan beberapa tipe pengering energi surya antara lain tipe "Teko Bersayap" (Yuwana et al., 2011, Yuwana et al., 2016, Yuwana et al., 2017) dan tipe YSD-UNIB12 (Yuwana, 2012). Tipe yang terakhir ini telah dimodifikasi untuk mengeringkan bahan pakaian (Yuwana et al., 2013). Baru-baru ini pengering ini dimodifikasi untuk dapat mengeringkan berbagai bahan, termasuk limbah kayu, dengan kapasitas $5 \mathrm{~m}^{3}$ volume bahan. Dalam praktek penggunaannya salah satu parameter yang perlu ditentukan adalah lama penyelesaian pengeringan. Dari aspek alat pengering parameter ini terutama dipengaruhi oleh jenis alat pengering dan kisaran suhu yang dikenakan sedangkan dari bahan ditentukan jenis bahan, kadar air awal dan dimensinya. Selanjutnya parameter ini dapat diduga kalau model kurva pengeringan ditemukan. Dua model kurva pengeringan yang biasa dipakai adalah "moisture ratio" berfungsi waktu pengeringan dan kadar air berfungsi waktu pengeringan. Moisture ratio ditentukan melalui kadar air produk yang dihitung berdasarkan dasar kering 
sedangkan kadar air produk secara praktis banyak ditentukan berdasarkan dasar basah.

Penelitian ini bertujuan untuk menentukan model peneringan dalam bentuk moisture ratio berfungsi waktu pengeringan dan kadar air berfungsi waktu pengeringan terhadap tandan kosong dan pelepah yang dikeringkan dengan pengering energi surya, pelepah sawit dan serabut tandan kosong yang dikeringkan dengan oven, dan selanjutnya menduga waktu penyelesaian pengeringannya untuk menghasilkan bahan kering dengan kadar air 10\% dasar basah.

\section{METODE}

Dalam penelitian ini dalakukan dua seri percobaan yaitu pengeringan tandan kosong dan pelepah sawit dengan energi surya dan pengeringan pelepah dan serabut tandan sawit dengan oven. Pengeringan energi surya dilakukan dengan menggunakan alat pengering energi surya tipe YSD-UNIB12. Pengering dibuat dari kerangka baja ringan ditutup dengan plastik UV $14 \%$ dengan bagian utama meliputi ruang pengering berisi 8 rak nilon berkerangka baja, cerobong, plenum, kolektor panas dan pintu, dan berkapasitas $5,04 \mathrm{~m}^{3}$ serta menempati area $5 \mathrm{~m} \times 3 \mathrm{~m}$. Cerobong berpenampang melintang $40 \mathrm{~cm} \times 60 \mathrm{~cm}$, dilengkapi outlet dan mempunyai tinggi $125 \mathrm{~cm}$ dari titik teratas atap ruang pengering. Plenum berukuran $2 \mathrm{~m} \mathrm{x} 3 \mathrm{~m} \mathrm{x}$ $0,5 \mathrm{~m}$ sebagai tempat menampunga udara panas dan kering yang berasal dari kolektor. Kolektor panas terdiri dari pelat seng gelombang bercat hitam luasan $3 \mathrm{~m} \mathrm{x}$ $1,55 \mathrm{~m} \times 2$ (kanan dan kiri), atap yang terbuat dari plastic UV 15\% dan isolator panas yang terbuat dari papan triplek dan dipasang di bawah pelat seng gelombang. Ujung bawah kolektor dilengkapi dengan inlet udara masuk dengan ukuran $15 \mathrm{~cm} \mathrm{x}$ $300 \mathrm{~cm}$. Pintu terbuat dari kerangka baja ringan sedangkan daun pintu terbuat dari plastic UV $15 \%$ dan berfungsi untuk memasuk-keluarkan rak pengering berisi produk yang dikeringkan. Pada saat operasi, bahan terlebih dahulu dimuat ke atas rak pengering dan dimasukkan ke dalam ruang pengering. Kolektor panas menyerap panas dari matahari dan panas yang diserap selanjutnya dipakai untuk memanaskan udara segar yang masuk melalui inlet. Udara panas masuk ke dalam plenum dan menerobos bahan yang berada di atas rak-rak pengering, menguapkan air bahan dan selanjutnya udara lembab yang meninggalkan rak pengering keluar melalui outlet. Karena terjadinya proses penguapan kadar air bahan turun sampai batas kadar air yang dikehendaki sebagai tanda proses pengeringan selesai. Sampel tandan kosong dan pelepah dari dua varietas sawit Dura dan Tenera dipersiapkan yang meliputi 5 sampel tandan kosong Dura dengan berat 274-339 gr, 5 sampel tandan kosong Tenera dengan berat 264-334 gr, 5 sampel pelepah Dura dengan berat 253302 gr, dan 5 sampel pelepah Tenera dengan berat 278-336 gr. Sampel diletakkan ke dalam pengering pada rak tingkat 3 dan diamati penurunan beratnya setiap satu jam dengan melakukan penimbangan dengan timbangan digital. Bersamaan dengan penimbangan pengamatan juga dilakukan terhadap suhu dan kelembaban relatif ruang pengering dan udara luar dengan menggunakan termohigrometer. Pengeringan dihentikan ketika berat sampel sudah mulai konstan.

Pengeringan dengan oven dilakukan dengan menggunakan oven stadar laboratorium yang sudah disetel suhunya $105^{\circ} \mathrm{C}$. Pada pengeringan pelepah, masing-masing 3 sampel dengan berat 1000 gr dari pelepah bagian pangkal, tengah dan ujung dipersiapkan untuk dikeringkan sedangkan untuk pengeringan serabut masing-masing 4 sampel dengan berat 100 gr dari tumpukan tandan kosong 
bagian luar dan bagian dalam di lapangan juga dipersiapkan untuk dikeringkan. Selama pengeringan dilakukan penimbangan berat sampel menggunakan timbangan digital dengan interval waktu satu jam. Pengeringan dihentikan setelah berat sampel hampir konstan.

Pada akhir akhir pengeringan berat kering setiap sampel ditentukan dengan metode oven, selanjutnya dengan diketahuinya berat kering ini kadar air sesaat untuk setiap sampel baik dinyatakan dalam dasar kering maupun dasar basah dapat dihitung. Kadar air pada berat sampel konstan dianggap sebagai kadar air lengas seimbang.

Kadar air sampel dihitung dengan menggunakan rumus (1) dan (2) berikut

$$
\begin{aligned}
& M C_{d b}=\frac{M_{w}-M_{d}}{M_{d}} \times 100 \\
& M C_{w b}=\frac{M_{w}-M_{d}}{M_{w}} \times 100 \\
& \mathrm{MC}_{\mathrm{db}}=\text { Kadar Air dasar kering }(\%) \\
& \mathrm{MC}_{\mathrm{wb}}=\text { Kadar Air dasar basah (\%) } \\
& \mathrm{M}_{\mathrm{w}}=\text { Berat basah sampel }(\mathrm{kg}) \\
& \mathrm{M}_{\mathrm{d}}=\text { Berat kering sampel }(\mathrm{kg})
\end{aligned}
$$

berdasarkan persamaaan (3) berikut

$$
M R=\frac{M C-M C_{e}}{M C_{i}-M C_{e}}
$$

MR = Moisture Ratio (desimal)

$\mathrm{MC}=$ Kadar air sesaat dasar kering (\%)

$\mathrm{MC}_{\mathrm{i}}=$ Kadar air awal dasar kering $(\%)$

$\mathrm{MC}_{\mathrm{e}}=$ Kadar air lengas seimbang $(\%)$

Data percobaan untuk setiap seri perlakuan dirata-rata dan selanjutnya dipresentasikan dalam bentuk kurva moisture ratio dan kadar air berfungsi waktu. Dari kurva kadar air berfungsi waktu dan menggunakan kadar air 10\% waktu penyelesaian pengeringan diprediksikan.

\section{HASIL DAN PEMBAHASAN}

Selama pengeringan suhu dan kelembaban relatif ruang pengering energi surya masing-masing adalah 42-54,5oC dan $17-35 \%$ sementara suhu dan kelembaban relatif udara luar masingmasing adalah 30-32,5oC dan 58-79\%. Kurva moisture ratio berfungsi waktu pengeringan disajikan pada Gambar 1 dan 2 sementara kurva kadar air berfungsi waktu pengeringan diperlihatkan pada Gambar 3 dan 4. 


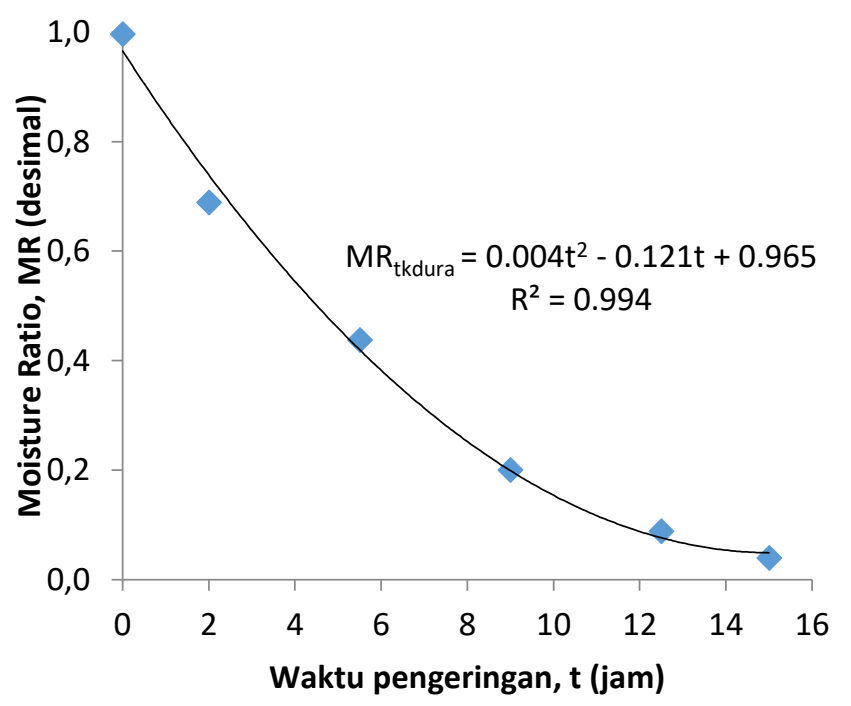

Gambar 1. Moisture ratio berfungsi waktu pengeringan dengan energi surya tandan kosong Varietas Dura

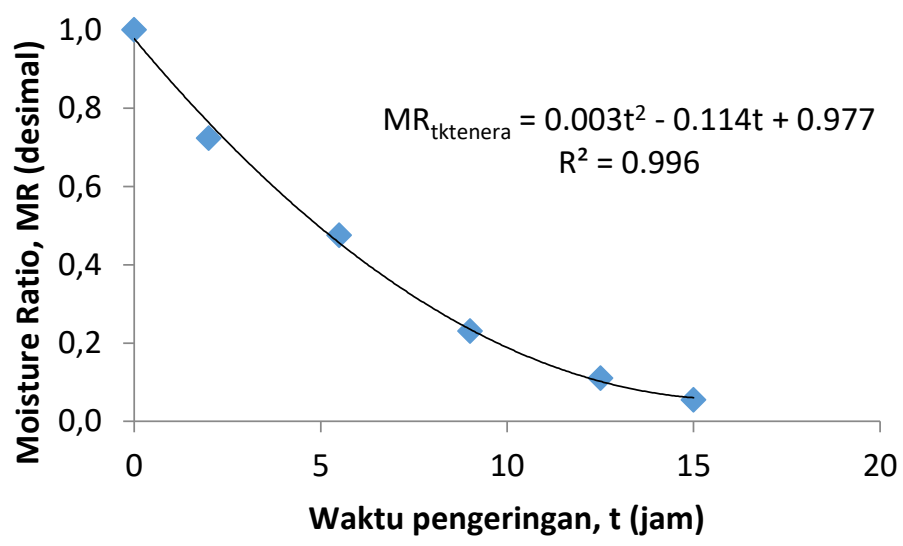

Gambar 2. Moisture ratio berfungsi waktu pengeringan dengan energi surya tandan kosong Varietas Tenera 


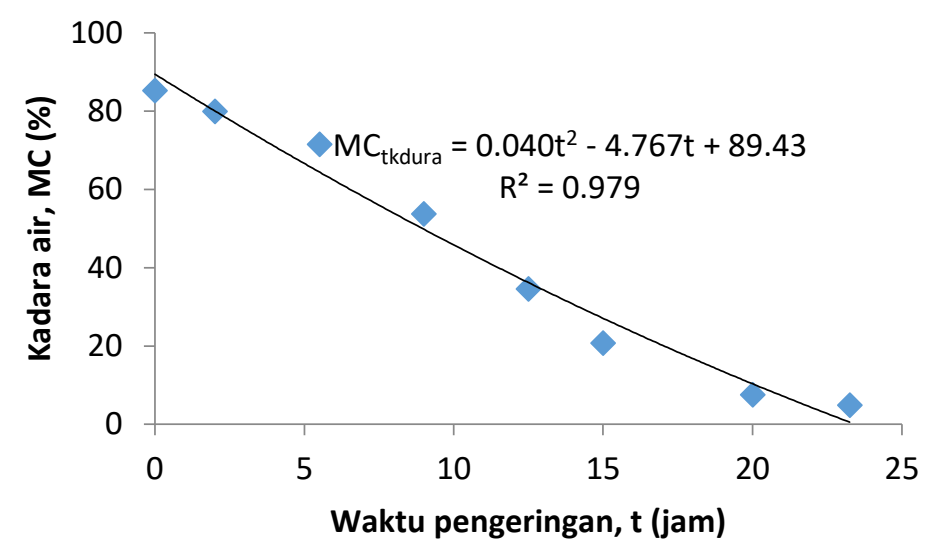

Gambar 3. Kadar air berfungsi waktu pengeringan dengan energi surya tandan kosong Varietas Dura

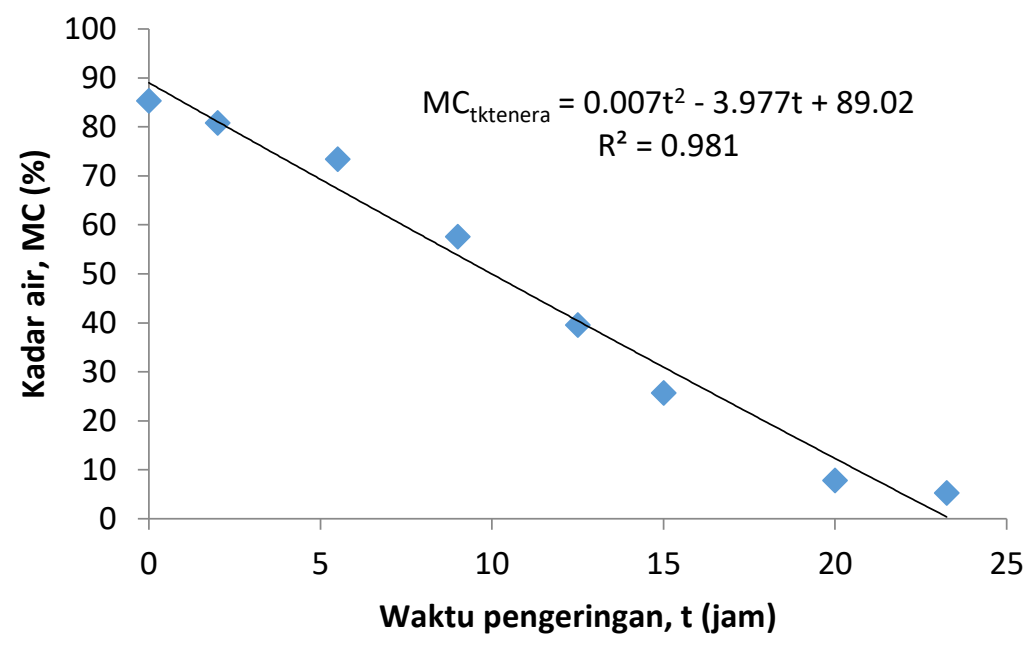

Gambar 4. Kadar air berfungsi waktu pengeringan dengan energi surya tandan kosong Varietas Tenera

Keempat kurve di atas berbentuk kwadratik dan dapat dikatakan bahwa bentuk kurva moisture ratio berfungsi waktu pengeringan mirip dengan bentuk kurva kadar air berfungsi waktu pengeringan. Dari Gambar 3 dapat diketahui bahwa waktu penyelesaian pengeringan untuk tandan kosong Varietas Dura adalah 20 jam sementara waktu penyelesaian pengeringan tandan kosong Varietas Tenera adalah 19,3 jam.

Kurva hubungan antara moisture ratio dan kadar air dengan waktu pengeringan energi surya untuk pelepah sawit dengan energi surya diperlihatkan masing-masing pada Gambar 5, 6, 7 dan 8. 


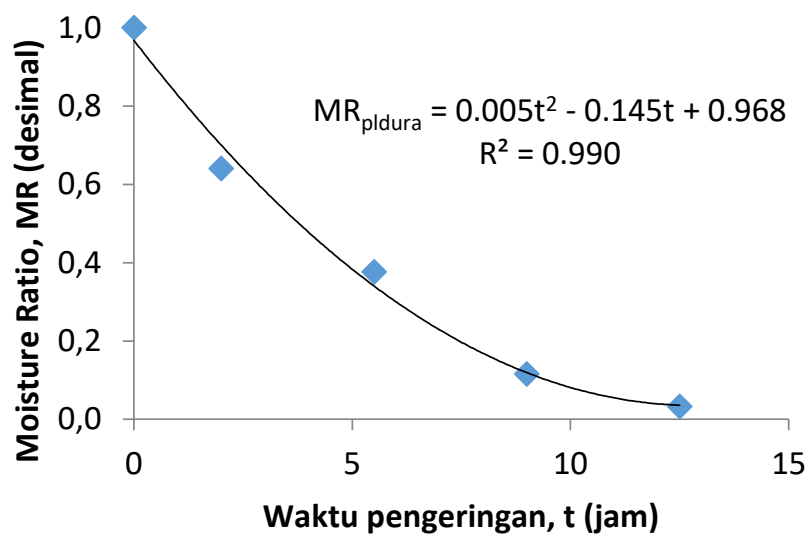

Gambar 5. Kurva hubungan antara moisture ratio dan waktu pengeringan dengan energi surya pelepah Varietas Dura

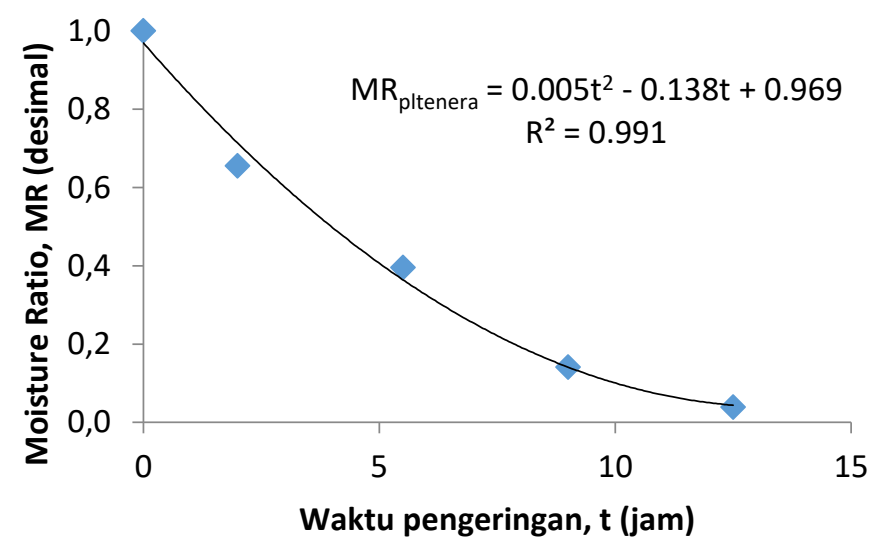

Gambar 6. Kurva hubungan antara moisture ratio dan waktu pengeringan dengan energi surya pelepah Varietas Tenera

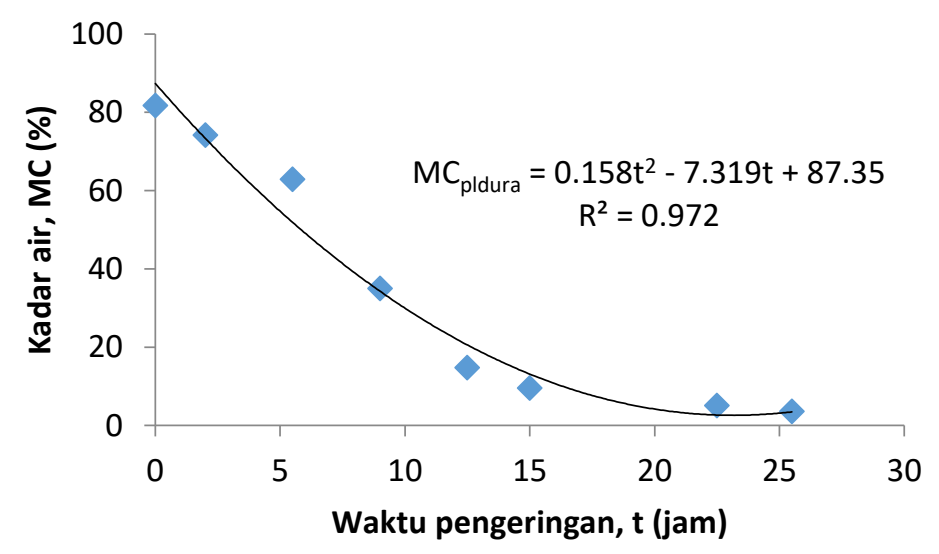

Gambar 7. Kurva hubungan antara kadar air dan waktu pengeringan dengan energi surya pelepah Varietas Dura 


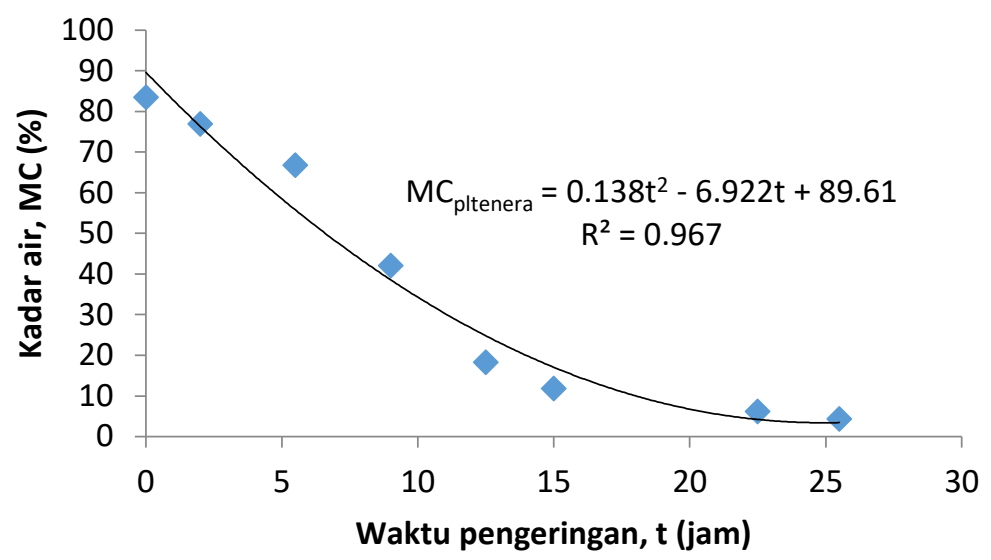

Gambar 8. Kurva hubungan antara kadar air dan waktu pengeringan dengan energi surya pelepah Varietas Tenera

Keempat kurva terakhir ini juga berbentuk kwadratik dan memperlihatkan bahwa bentuk kurva moisture ratio berfungsi waktu juga mirip dengan bentuk kurva kadar air berfungsi waktu untuk pelepah sawit. Dari kurva Gambar 7 dan 8 ditemukan bahwa waktu penyelesaian pengeringan untuk pelepah Varietas Dura dan Tenera masing-masing adalah 16,3 jam dan 17,9 jam.
Gambar $\quad 9 \quad$ sampai 11 memperlihatkan kurva hubungan antara moisture ratio dan waktu pengeringan untuk pelepah sawit hasil pengeringan oven sedangkan kurva hubungan antara kadar airnya dengan waktu pengeringan ditunjukkan oleh Gambar 12 sampai 14.

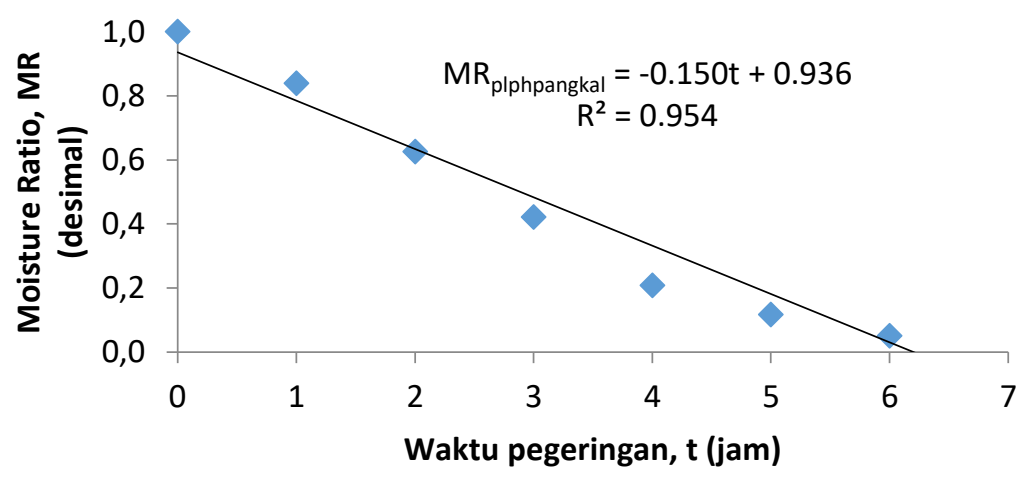

Gambar 9. Kurva hubungan antara moisture ratio dan waktu pengeringan pelepah sawit bagian pangkal dengan oven 


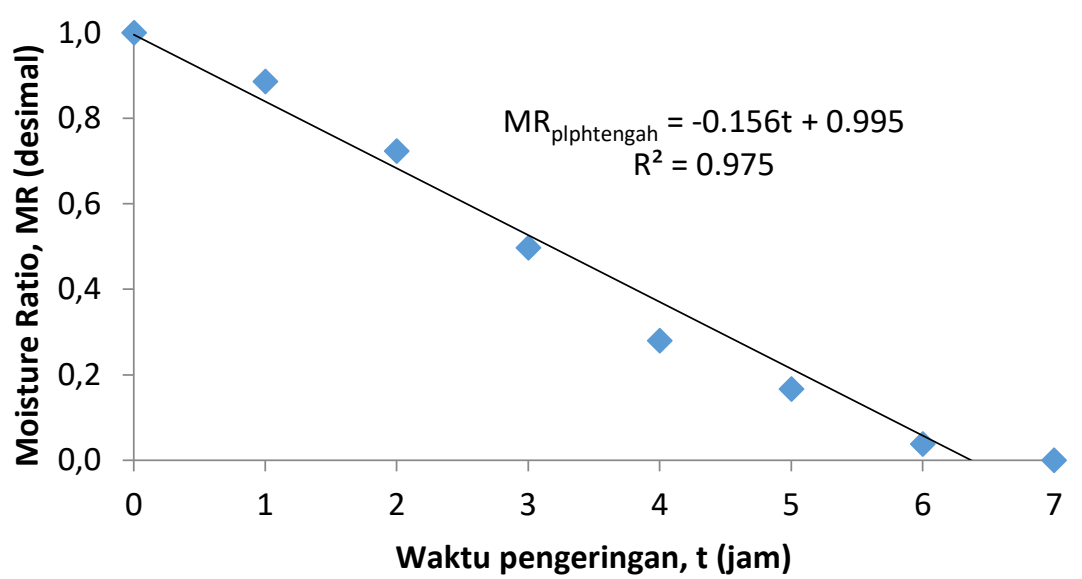

Gambar 10. Kurva hubungan antara moisture ratio dan waktu pengeringan pelepah sawit bagian tengah dengan oven

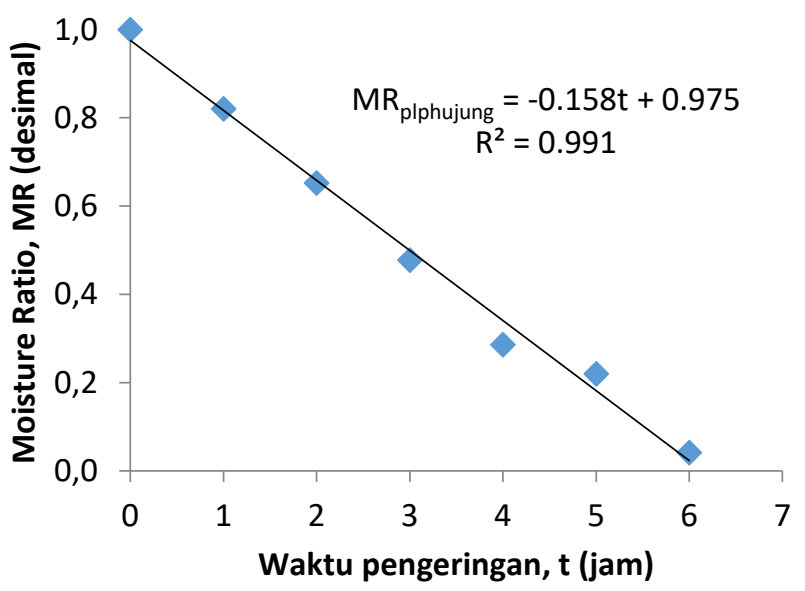

Gambar 11. Kurva hubungan antara moisture ratio dan waktu pengeringan pelepah sawit bagian ujung dengan oven

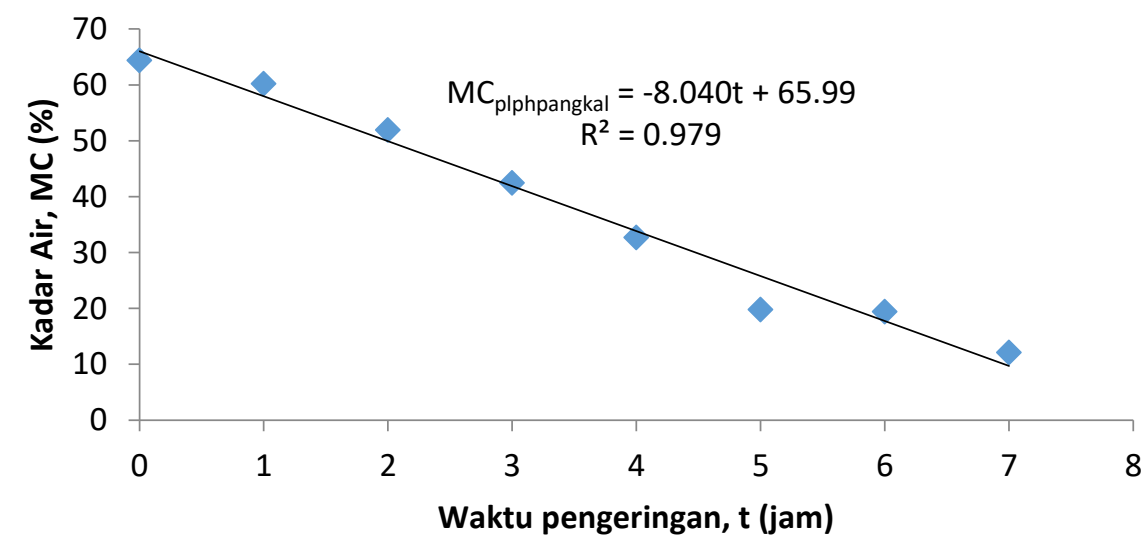

Gambar 12. Kurva hubungan antara kadar air dan waktu pengeringan pelepah sawit bagian pangkal dengan oven 


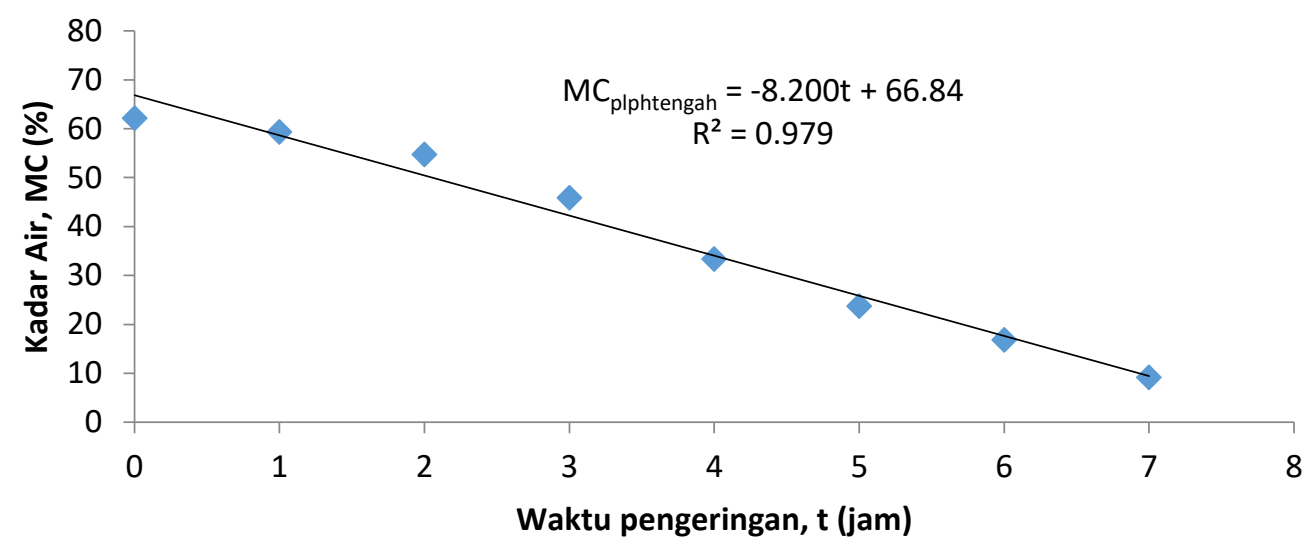

Gambar 13. Kurva hubungan antara kadar air dan waktu pengeringan pelepah sawit bagian tengah dengan oven

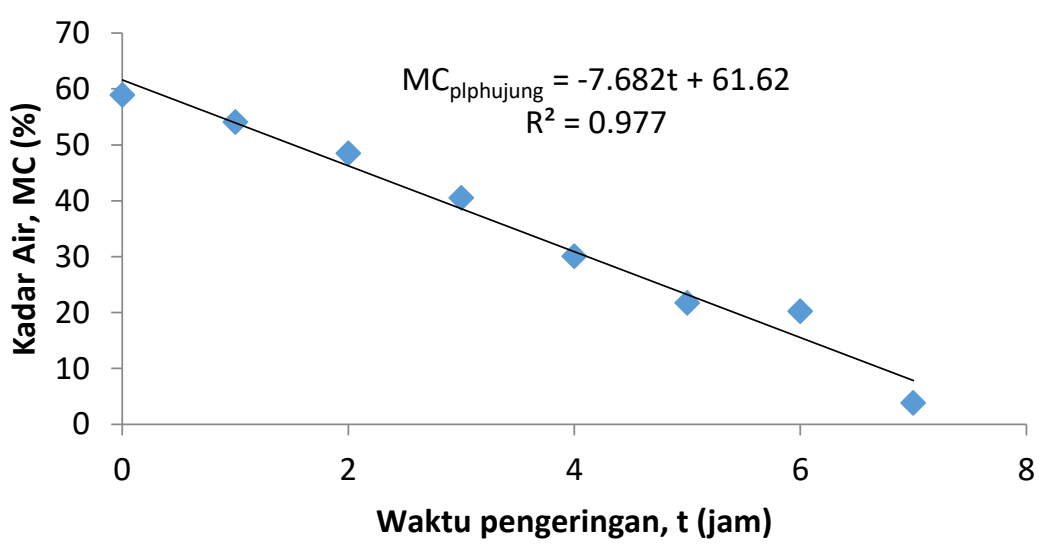

Gambar 14. Kurva hubungan antara kadar air dan waktu pengeringan pelepah sawit bagian ujung dengan oven

Keenam grafik tersebut berbentuk linier dan dari kurva-kurva pada tiga Gambar terakhir ini dapat ditemukan bahwa waktu penyelesaian pengeringan pelepah sawit dengan oven masingmasing adalah 7,1 jam, 6,9 jam dan 5,0 jam untuk pelepah bagian pangkal, bagian tengah dan bagian ujung.
Kurva-kurva hubungan antara moisture ratio dan kadar air dengan waktu pengeringan serat tandan kosong dengan oven diperlihatkan oleh Gambar 15, 16, 17 dan 18. 


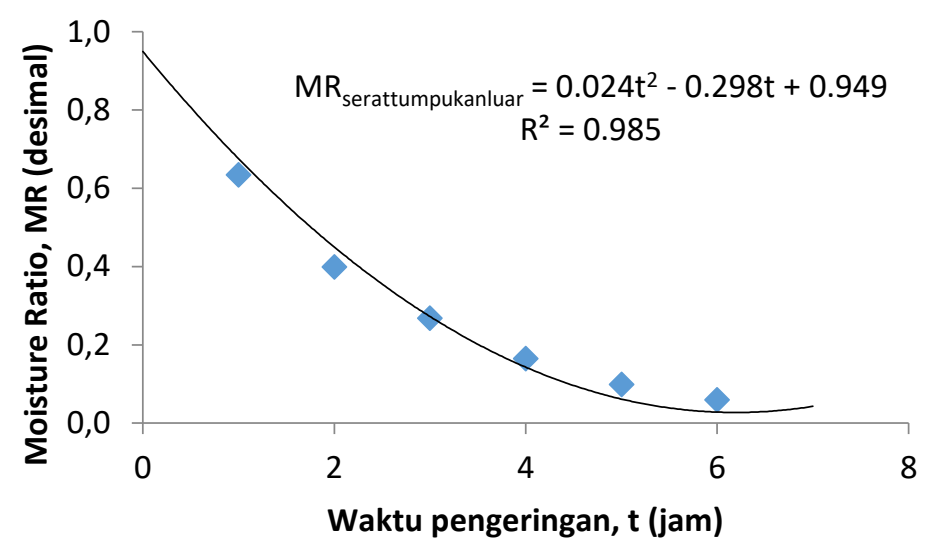

Gambar 15. Kurva hubungan antara moisture ratio dan waktu pengeringan serat tandan kosong tumpukan bagian luar dengan oven

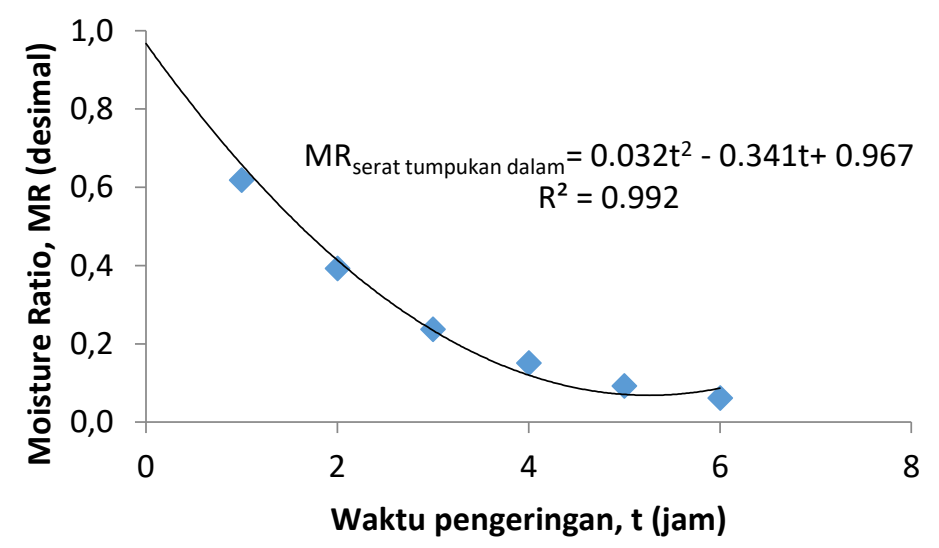

Gambar 16. Kurva hubungan antara moisture ratio dan waktu pengeringan serat tandan kosong tumpukan bagian dalam dengan oven

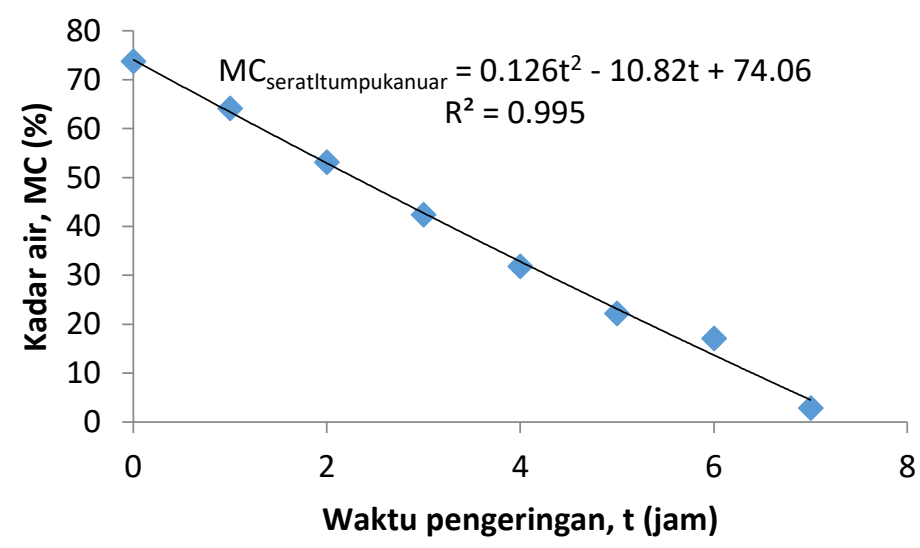

Gambar 17. Kurva hubungan antara kadar air dan waktu pengeringan serat tandan kosong tumpukan bagian luar dengan oven 


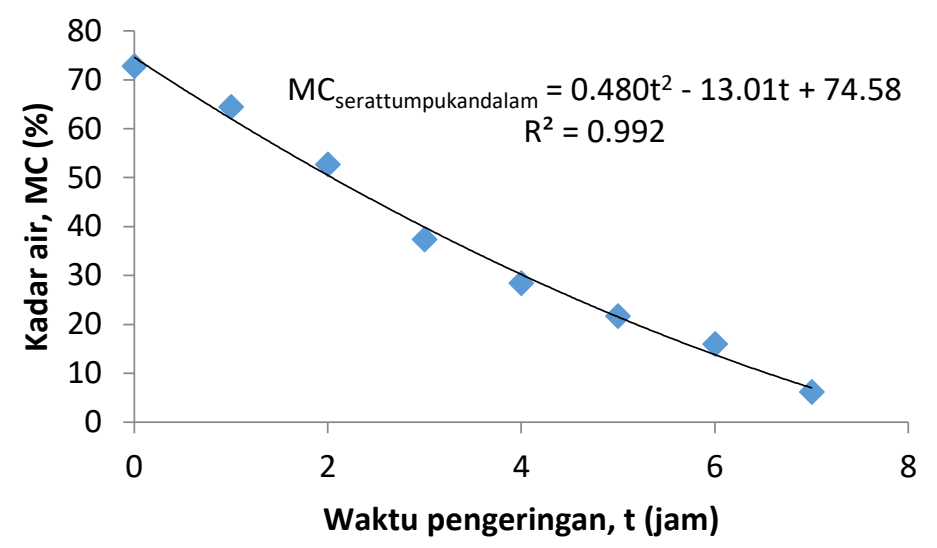

Gambar 18. Kurva hubungan antara kadar air dan waktu pengeringan serat tandan kosong tumpukan bagian dalam dengan oven

Kurva-kurva pada empat gambar terakhir ini berbentuk linier dan dari dua kurva dari dua gambar terakhir diperoleh bahwa lama pengeringan dengan oven adalah 6,4 jam dan 6,2 jam masing-masing untuk serat yang berasal dari tumpukan tandan kosong bagian luar dan bagian dalam.

\section{KESIMPULAN}

Kurva moisture ratio berfungsi waktu pengeringan tandan kosong dan pelepah sawit dengan energi surya bersuhu 42oC sampai 54,5oC berbentuk kwadratik sedangkan kurva moisture ratio berfungsi waktu pengeringan pelepah dan serat tandan kosong dengan oven bersuhu 105 oC masingmasing berbentuk linier dan kwadratik. Bentuk kurva hubungan antara kadar air bahan yang ditentukan dengan dasar basah dengan waktu pengeringan mirip dengan bentuk kurva moisture ratio berfungsi waktu pengering. Lama pengeringan dengan pengering energi surya untuk menghasilkan bahan kering berkadar air $10 \%$ untuk tandan kosong kelapa sawit Verietas Dura dan Tenera masing-masing adalah 20 jam dan 19,3 jam sedangkan untuk pelepah sawit vrietas Dura dan Tenera masing-masing adalah 16,3 jam dan 17,9 jam. Lama pengeringan dengan oven untuk menghasilkan bahan kering berkadar air $10 \%$ untuk pelepah sawit adalah 7,1 jam, 6,9 jam dan 5,0 jam masingmasing untuk pelepah bagian pangkal, bagian tengah dan bagian ujung sedangkan lama pengeringan untuk serat tandan kosong adalah 6,4 jam dan 6,2 jam masing-masing untuk serat yang berasal dari tumpukan di lapangan tandan kosong bagian luar dan bagian dalam.

\section{ACKNOWLEDGEMENT}

Ucapan terima kasih dan penghargaan disampaikan kepada Paulina, Wasih dan Delta Majid yang telah membantu pelaksanaan penelitian ini.

\section{DAFTAR PUSTAKA}

Direktorat Jenderal Perkebunan. 2015. Rencana Strategis Direktorat Jenderal Perkebunan Tahun 20152019. Dirjend. Perkebunan, Jakarta. 274 halaman.

Fauzi, Y., Y.E. Widyastuti, I. Setyawibawa and R. Hartono. 2012. Kelapa Sawit: Budidaya, pemanfaatan, hasil dan limbah, analisis usaha dan pemasaran. Penebar Swadaya, Jakarta.

Frike, T.B. 2009. Buku Panduan pabrik kelapa sawit skala kecil untuk 
produksi bahan baku bahan bakar nabati (BBN) . Development Alternatives, Inc. for the United States Agency for International Development under Contract No. 497-M-00-05-00005-00. 36 pgs.

Goenadi, D.H., W.R. Susila and Isroi, 2008. Pemanfaatan Produk Samping Kelapa Sawit sebagai Sumber Energi Alternatif Terbarukan. Badan Litbang Pertanian, Jakarta.

SNI 12-6094-1999. Isi jokkursi dari serat sabut kelapa. Badan Standarisasi Nasional.

SNI 01-6235-2000. Briket arang kayu. Badan Standarisasi Nasional.

Sulaiman, F., N. Abdullah and Z..Aliasak. 2013. Solar drying system for drying empty fruit bunches. Journal of Physical Science 24(1):75-93.

Yuwana, Y., B. Sidebang and E. Silvia, 2011. Temperature and Relative Humidity Gains of "Teko Bersayap" Model Solar Dryer (A
Research Note). Proceedings of the International Seminar of CRISU and CUPT "Exploring Research Potential" Session Enery, Education and Others, Palembang, Indonesia. ISBN 978979-98938-5-7 p 221-227.

Yuwana, Y. 2012. Pengeringan ikan lele (clarias batracus) dengan pengering tipe teko bersayap. Jurnal Agroindustri 2(1) : 14-20.

Yuwana, Y., B. Sidebang and E. Silvia, 2013. Kinerja pengering energi surya model YSD-UNIB12 termodifikasi untuk mengeringkan bahan pakaian. Jurnal Agroindustri 3(2) : 98-104.

Yuwana, Y., Y, B. Sidebang and E. Silvia, 2016. "Teko Bersayap" Model Solar Dryer for Fish Drying. Jurnal Agroindustri 6(2) : 1-6.

Yuwana, Y., R.N.B. Tarigan and E. Silvia. 2017. Solar Drying Modes of Catfish (Clarias gariepinus). IJEI. 6(4): 06-12. 